\title{
Minority Youth, Crime, Conflict and Belonging in Australia
}

\author{
JIMI Special Issue on Immigrant Crime \\ By \\ Jock Collins
}

Professor of Economics, University of Technology, Sydney (UTS) jock.collins@uts.edu.au and

Carol Reid,

Centre for Educational Research, University of Western Sydney (UWS)

c.reid@uws.edu.au 


\section{Introduction}

One consequence of the increasing migration flows that have accompanied globalisation to traditional settler immigration countries (Australia, USA, Canada and New Zealand), traditional emigration countries (such as Ireland and Italy) and those in between (such as France, the UK, Germany) is that the ethnic minority populations of contemporary western societies has increased significantly in the past decades (Castles and Miller, 2009). As a result, the size and diversity of ethnic minority youth populations of western countries, some first generation immigrants, others second or later generations, has increased significantly, particularly in the metropolises of western nations. At the same time, ethnic minority youth in contemporary societies in Europe, North America and Australasia have been increasingly linked to crime, criminal gangs and anti-social behaviour. To the critics of immigration and cultural diversity, ethnic minority youth are a threat to the social cohesion of western societies, particularly when the religious affiliation of the youth population is, increasingly, non-Christian, with the values and identities of Muslim youth in particular characterised as not only being incompatible with western society but a threat to it (Huntington, 1997; 2004).

Concern about crime and fear of crime appear to be one of the characteristics of the age, not just in Australia but also in all western societies. The issue of ethnic youth crime has been of great public concern in Sydney since late 1998 (Collins, Noble, Poynting, \& Tabar, 2000). In particular, media headlines have emphasized the problems of youth crime and youth gangs operating in south western Sydney (Anti-Discrimination Board of New South Wales, 2003). Crime and fear of crime have increasingly been linked to immigration and immigrants, and the immigrant crime issue has captured media headlines and shaped political discourses and electoral outcomes in an unprecedented way (Collins, Noble, Poynting, \& Tabar, 2000; Collins 2003). At the same time, images of inter-ethnic youth conflict in Paris, Toronto, Los Angeles and Sydney have raised concerns about the ability of immigrant youth to identify with, and integrate into, the nations and neighbourhoods where they settle in a cohesive, inclusive, way. The Cantle Report (2002) into the Bradford, Burnley and Oldham riots highlighted the segregation of minority youth and the

separation in their daily lives from white youth, emphasising the 'depth of polarisation' between white and minority youth in Britain, leading them to live disconnected 'parallel lives'. 
In this article we look at aspects of criminality, anti-social behaviour, national identity and belonging of ethnic minority youth in Australia, a traditional settler immigration society with more immigrants and greater ethnic diversity than most western countries. We focus in particular on Sydney, Australia's largest city which takes about 40 per cent of Australia's annual immigration intake where 58 per cent of the population are first and second generation immigrants. Sydney is also the main centre of the nation's Middle Eastern immigration, with seven out of every ten (107 405 or $72.2 \%$ ) of Australia's Lebanese immigrants settling in Sydney (Collins, 2005, pp. 190-2).

The structure of this article is as follows. In section 2 we explore the issue of ethnic youth crime in Sydney, particularly those related to young people of 'Middle Eastern appearance', probing events, discourses, and evidence and policy responses, situated within a broader international literature on ethnic youth crime. In section 3 we then look at the Sydney Cronulla Beach riots of December 2005, set against the recent historical background on ethnic minority conflict and riots in suburban areas of high immigrant settlement in global cities such as London, Paris, Toronto and Los Angeles. In section 4 we draw on a survey of 339 young men and women living in western and south-western Sydney conducted in 2007 to explore issues of national identity and belonging among young people of diverse ethnic and religious background living in Sydney today. The final section presents a brief overview and conclusion.

\section{Immigrant crime in Australia}

There is a strong international literature on the criminalising of immigrant minorities in many western countries (Tonry ed., 1997; Hawkins ed., 1995; Bowling \& Phillips, 2002; Schissel \& Brooks eds., 2002), particularly in relation to black immigrants in countries like Canada (James 2002; Chan and Mirchandani eds, 2002) and the UK (Gilroy, 1987; Cook \& Hudson 1993; European Monitoring Centre on Racism and Xenophobia 1999; Cathcart, 2000). A common theme that emerges from this literature is the social construction of ethnic criminality (Hall, Critcher, Jefferson, Clarke, \& Roberts, 1978; Webster, 1997; Henry, Hastings, \&. Freer, 1996), linked to the fear of the stranger or 'Other'. In this way ethnic or immigrant minority crime is racialised, constructed as worse than other crime, and responded to in an asymmetrical fashion when compared to non-immigrant crime. 
The supposed links between immigrant minorities and criminal behaviour is a recurring theme in Australian immigration history (Francis, 1981; Hazlehurst, 1987). This had led to periodic research and inquiry into immigrant crime in the post-1945 decades (Mukherjee, 1999) when, at various times, Greeks, Italians, Lebanese, Chinese and Turkish immigrants have been linked to international criminal gangs. During this period, immigrant minorities have been constructed as criminal with their (inferior/dysfunctional) ethnicity or culture both an explanation for their criminality and the reason why immigrant crime is something to be feared more than other crime (Lupton, 1991). Over many decades media representations of immigrant minorities have produced and reproduced stereotypes of violent and criminal communities (Goodall, Jakubowicz, Martin, Randall, \& Seneviratre, 1994) while the suburbs in which they concentrate have been depicted as dangerous and unsafe (Dreher, 2000; Castillo \& Hurst, 2000).

The issue of immigrant crime rose to new heights in Sydney since the late 1990s when the terms 'ethnic gangs', ‘ethnic youth gangs', 'Middle Eastern gangs', 'Lebanese gangs' and 'immigrant gangs' - always imprecise in their construction -recurred with amazing frequency in Sydney media headlines (Ethnic Communities Council of NSW, 1999; Collins, Noble, Poynting, \& Tabar, 2000; Poynting, Noble, Tabar

, \& Collins,. 2004; Sheehan, 1998). In this environment, 'Middle Eastern', 'Arabic' and 'Muslim’ are minority immigrant identities that are increasingly criminalized in recent media and popular discourse in Australia (Manning, 2004; 2006) and other nations, with terrorism the most extreme form of criminality and anti-social behaviour. Central to this criminalised and racialised discourse is 'the Arab Other', a supposedly homogeneous category which includes people from quite diverse ancestries, religious backgrounds and quite distinct histories constructed as essentially and pathologically evil, inhuman, violent and criminal (Poynting, 2000; Poynting, Noble, Tabar, \& Collins, 2004). As a result of these associations, whole minority immigrant communities are made to share the burden of blame for terrorism and crime while the accused - mostly second generation immigrants born in Australia - have been robbed of their nationality: they are reported as 'Lebanese’ or 'Middle Eastern', and never ‘Australian'. This approach not only robs these youth of their Australian identity, it also shifts the focus away from them being victims of crime to be consoled and reaffirmed, to that of perpetrators, to be feared, to be scorned and to be excluded. 
The media construction of minority immigrant criminality is of course not restricted to Australia. As Bowling and Phillips (2002, p. 79) put it, "the media and political reactions to the public disorders [in Britain] of the late 1970s and 1980s also contributed significantly to popular understandings of black people as disorderly and criminal”. In Canada (Henry \& Bjornson, 1999; Sacco, 2000; James, 2002; Wortley, 2002) and Europe (Gilroy, 1987; Webster, 2001; European Monitoring Centre on Racism and Xenophobia, 1999) the role of the media in constructing racial stereotypes of immigrant criminality has attracted increasing attention. This is particularly the case since politicians across the political spectrum have opportunistically played on immigrant law and order issues, and on the growing number of undocumented immigrant issues in their election campaigns in Europe, North America and Australia. Post 9/11, immigrants of Muslim faith have been a strong target for political parties from the far-right, particularly in Europe. It seems that the current global financial crisis, and the global recession that has followed it, will only exacerbate this tendency. In the recent 2009 European Parliament elections, for example, the British National Party won its first two seats while other anti-immigration far-right parties in other countries also won seats in Finland, Slovakia, Hungary, Bulgaria and the Netherlands, and there was increasing support for them in Belgium, and Romania.

Despite the controversy that surrounds the issue of ethnic or immigrant crime in Australia and elsewhere, there has been surprisingly little solid research on the subject. The data is very inconclusive about the rates of criminality of immigrant or ethnic minorities. Data based on imprisonment rates by birthplace does show that immigrants of certain birthplace groups Lebanese (1.6 per 1000 of population), Vietnamese (2.7) and New Zealanders (1.6) - are overrepresented in the criminal justice system while other groups of immigrants - those born in Italy (0.6), Greece (0.5) and the UK and Eire - (0.6) are under-represented when compared to the Australian born (=1) (Mukherjee, 1999, p. 8). This data is not only dated, it is limited to only one Australian state (Victoria) and thus very inadequate if the intention is to form a rigorous judgment on the criminality of immigrants in Australia. As Mukherjee (1999, p. 4) points out, only one in ten crimes are solved, so that imprisonment data refers only to the tip of the crime iceberg. Moreover, birthplace does not equate with ethnicity: a person born in Malaysia, for example, might be of Chinese, Indian or Malaysian background. While police discretion mediates between criminal acts and the extent to which these acts and their perpetrators are taken further into the criminal justice 
system a suspect's ethnicity does make a difference (Keith \& Murji, 1993). Space is therefore provided for police and/or community racism to influence arrest and imprisonment rates in countries such as Australia (Chan, 1994; 1997), Canada (Henry \& Bjornson, 1999; Wortley 2001) and the United Kingdom (Holdaway, 1996; Phillips \& Brown, 1998).

A survey conducted in Sydney in 2001, which inquired into the perceptions and experiences of 445 youth from 24 different birthplace groups, found that minority youth are more likely to be victims of criminal activity than engaged in criminal activity (Collins, Noble, Poynting, \& Tabar, 2002). About half of those surveyed thought that criminal gangs and youth gangs were associated with particular ethnic groups, while one-half disagreed with this proposition. Those who linked youth and criminal gangs to specific ethnic groups nominated 'Lebanese, Middle Eastern or Arabic', ‘Asian, Chinese or Vietnamese’ and 'Pacific Islander or Tongan' as the ethnic groups linked to criminal and youth gangs. However, only one in ten of the youth respondents said that the friendship group that they hang around with in public spaces was a gang. This suggests that there is an exaggeration in the public mind about the number of ethnic gangs and youth gangs. This does not deny that there are criminal and youth gangs that have ethnicity as the common denominator, but it does suggest that most youth gathered together in public spaces such as shopping malls are not members of youth gangs. Two-thirds of young people surveyed thought that police picked on groups of young people and named 'Lebanese, Middle Eastern or Arabic', 'Asian, Chinese or Vietnamese' and 'Pacific Islander or Tongan' as the ethnic groups that police picked on most.

Moreover, media 'loudness' about the criminality of immigrant minorities is contrasted to relative media 'deafness' about the victimology of the same immigrant minorities. Reporting on a study of the Toronto media, Wortley (2002, p, 64) concludes that "the media are much more likely to communicate the race of criminal offenders than the race of crime victims”. Similarly, Bowling and Phillips (2002, p. 14) argue in relation to the British experience "racist violence has a significant impact on minority communities, leaving them insecure and avoiding many public places for fear of attack" with ethnic minorities in the UK generally at greater risk of criminal victimisation (Bowling and Phillips, 2002, p. 89). There is strong evidence that immigrant minorities, particularly those of Islamic faith, have been victims of crime, particularly following 9/11 and the two Bali bombings (Poynting \& Noble, 2004; Collins, 2007a). 
Nevertheless, it is clear that in a multicultural society such as Australia and in cosmopolitan cities such as Sydney criminals will come from all birthplaces and ethnic backgrounds. What is not clear is whether certain immigrant groups, youth and adults, are more criminal than others and, if so, the reasons for this. When immigrant minorities do have higher rates of incarceration than nonimmigrants it is possible that it is the relative socio-economic disadvantage of immigrant minorities compared to the majority white population in Australia (Collins, 2000) and other countries such as the UK (Solomos, 1993; Skellington, 1996) and Canada (Henry, Tator, Mattis, \& Rees, 2000; Satzewich ed., 1998) that is the explanation rather than the supposed dysfunctional ethnic or cultural traits of homogenized immigrant minorities. This is more than an academic debate: it impacts on the policy responses to crime. One explanation leads to a mobilization to stop or reduce the immigration of minorities, and/or to have immigrant community leaders such as Imams take the responsibility for responding to these problems. The other response is to conceptualise these problems as "ours", not 'theirs, to see these as (often transitory) problems of young individuals, not whole communities and to explore policies to reduce the socio-economic disadvantage of immigrant minorities. This latter point is conveniently ignored in much media discourse on immigrant criminality in Sydney (Henry \& Bjornson, 1999; Anti-Discrimination Board of New South Wales, 2003). A moral panic reinforces prejudicial stereotypes about immigrant and religious minorities and directs attention, research and resources away from the policy responses that need to be introduced to respond to the reality that criminals come from all ethnic, religious and cultural backgrounds, including the dominant host culture. Policies related to employment, education, urban renewal, public housing, policing, media and social justice are particularly important responses to concerns about minority youth criminality and anti-social behaviour. This is particularly evident in analyses of riots and social conflict involving inter-ethnic conflict between minority immigrant youth and white majority youth.

\section{Inter-ethnic youth conflict: There's a riot going on.}

One dimension of the debates about the impact of the growing number and growing cultural and religious diversity of immigrant and ethnic minority youth in western societies today centres on youth riots that have emerged in the cities of many countries over the past two or three decades. 
Britain experienced "race riots" in Brixton of the early 1980s (Solomos, 1993) with Afro Caribbean immigrants the centre of the conflict. In May 1992 the Los Angeles "race riots" left a staggering legacy: 54 dead; 2383 injured; 17000 people arrested; 5200 buildings damaged or destroyed by fire; losses estimated to be \$US 1 billion immigrant societies (Newsweek May 18 1992 p. 45). In the same month as the LA riot racial conflict erupted on the streets of Toronto, Canada's largest immigrant city, where about 1000 people, mostly youth ran through downtown Toronto streets vandalising property and breaking into stores.. A decade later, inter-ethnic conflict ignited in Burnley in Lancashire and Oldham in Greater Manchester in the UK in 2001 with Asian immigrant youth in conflict with White youth. In the first week of November, 2005, following the electrocution of two Muslim youth fleeing from police, Muslim youth who lived in the public housing estates in the North-western suburbs of Paris initiated a series of riots that spread to many other Paris suburbs, with thousands of cars burnt and confrontation with police and authorities a nightly occurrence for nearly a month.

While these instances of ethnic or racial conflict are complex, and could not be understood through the simple dichotomy of Black $v$ While race riots, they had a number of things in common. Issues of high unemployment, poor public housing, urban decline, inappropriate policing responses lay behind these riots. The young male immigrant minorities at the centre of the conflict generally came from socially disadvantaged families and neighbourhoods. In all instances they involved immigrant minority youth who were racialised minorities in their host country; mostly they were young men who were involved in the conflict. In each case relations between immigrant minorities and police before and during the events of ethnic conflict were a catalyst to conflict, with subsequent inquiries in many cases recommending substantial changes to methods of policing and attitudes and practices of police. In each country that experienced riots minority immigrant youth experienced higher rates of unemployment than average, lower educational outcomes, and were often housed in public housing estates. The unemployment rate for Muslim youth in the Paris North-western suburbs in 2005, for example, was over 50\%, while rates of unemployment among Pakistani, Bangladeshi and Caribbean youth in the UK have been much higher that for whites for decades (Bam-Hutchison, 2009). In each case right wing politicians strengthened their antiimmigration policies while conservative commentators sharpened their political rhetoric against immigration and multiculturalism, pointing to the problems that minority youth, particularly, post 
9/11, those of Muslim faith, had in identifying with their new society. In each case populist pundits, such as Samuel Huntington (1997; 2004) in the USA and Paul Sheehan (1998; 2006) in Australia, pronounced the beginning of the end for ethnically diverse societies.

In Australian the Cronulla beach riots on Sunday 11th December, 2005, on Sydney's Cronulla Beach sent a tremor through Australian community relations. Images of around five thousand drunk white males chasing and bashing isolated men and women of "Middle Eastern appearance" were compelling viewing for media audiences in Sydney, the rest of Australia, and internationally (Poynting, 2006). By nightfall, at least 13 people, most of “Middle Eastern appearance”, were injured while police made 12 arrests (Kennedy, Murphy, Brown, \& Colquhoun, 2005), while police reported that it was a miracle that no one was killed (Overington \& Warne-Smith, 2005). Days later a retaliatory car-gang of males of "Middle Eastern appearance" sought revenge in a smash, bash and flee raid on the suburbs surrounding Cronulla. For months following, an unprecedented large police presence dominated the 'sand-scape' of Sydney's famous beaches, successfully preventing further reverberations and escalation of racial conflict.

The immediate catalyst for the riot was a fight on Cronulla beach days earlier between three offduty surf-lifesavers and a group of four Lebanese-background young men. The beach is a sacredsite of white Australian youth masculinity, with life-savers an iconographic image of (white) Australian male identity. This fight was widely reported by the Sydney tabloid newspapers and talkback radio in the following days, with accounts exaggerating the numbers involved and, the brutality of the attack and the frequency of such events (Poynting, 2007, p. 159). Widely-circulated text messages called for vigilante action by outraged “Aussies” to meet at Cronulla beach (located in the Sutherland Shire) on Sunday 11 December to 'take back their beach'. The text of one SMS message was reprinted in the Daily Telegraph, a Sydney tabloid with wide circulation: “This Sunday every Aussie in the Shire get down to north Cronulla to help support Leb and wog bashing day...Bring your mates and let's show them that this is our beach and they are never welcome...let’s kill these boys” (McIlveen \& Downie, 2005). 
However, the broader catalyst for the Cronulla beach riot is found years earlier. At the international level, post 9/11, Muslim minorities have been criminalised in western societies like Australia. At the national level, conservative Australian Prime Minister, John Howard, won the 2001 election by successfully playing the 'race card' by sending the Australian navy to intercept the MV Tampa (which had picked up a distressed boat carrying asylum seekers from the Middle East off the North Western Australian coast) to prevent the 'boat people' from landing on Australian soil and lodge claims for refugee asylum (Marr \& Wilkinson, 2003). At the local level, the New South Wales Carr Labor Government ran a strong 'law and order' political campaign repeatedly leveraged on media reports about the threat of Lebanese and Middle Eastern criminal gangs in Sydney (Poynting, Noble, Tabar, \& Collins, 2004). At the same time, widespread media coverage of 'ethnic gang rapes' in Sydney in 2000, leading to the conviction of a group of Lebanese-Australian youth (brothers Mohammed and Bilal Skaff and others), assisted in constructing an image of Muslim/Lebanese/Middle Eastern youth as 'monsters', 'wild animals' and 'barbarians' (Dagistanli, 2007: p. 182). As Poynting (2007: p.168) argues, these factors were woven into a moral panic by media and political actors about Lebanese youth gangs who terrorise 'our' streets, constituting a "permission to hate” Muslim, Arab and other minority communities in Sydney.

The Cronulla riots are thus an expression of ethnic tensions in one of the world's most cosmopolitan cities. They demonstrate that a long and persistent tendency of racist responses to minority immigrant groups in Australia is a critical challenge for Australian cosmopolitan society (Markus, 2001). This racism has been refreshed and reshaped following the events of 9/11 and the Bali, London and Madrid terrorist attacks and the subsequent criminalising of Muslim and Middle Eastern immigrant minorities in Australia and other western countries (Poynting, Noble, Tabar, \& Collins, 2004; Forrest \& Dunn, 2007; Dunn \& Forrest, 2008). Racism needs continuous vigilance on the part of governments and policy makers in Australia. But set against the history of ethnic relations in Australia and against contemporary instances of ethnic conflict in Europe and North America (Collins, 2007b), the Cronulla riots hardly constitutes strong evidence to support the arguments of the critics of Australian immigrant minorities and immigration policy such as Geoffrey Blainey (1984) who, echoing earlier 'blood on the streets' sentiments of Enoch Powell in 
Britain, argued that the presence of immigrant minorities would inevitably lead to conflict in the suburbs of high immigrant concentration in Australian cities.

The Cronulla riots did not occur in the 'frontline' suburbs of diverse, immigrant minority settlement, such as those south western suburbs of Lakemba or Fairfield or Liverpool, but at Cronulla beach, the diamond of the Sutherland Shire, Sydney's white enclave. No one died, though there was personal injury and property damage, as well as a great deal of damage to Sydney's international reputation as a tolerant, cosmopolitan, global city. When compared with earlier Australian history and contemporary western history, the Cronulla riots don't rate very highly on the seismograph of ethnic conflict. But the Cronulla riots do reflect the contradictory tendencies of social cohesion and social conflict that have accompanied increasing immigrant diversity amid a backdrop of persistent, though changing, racism. Yet in a cruelly ironic way, the Cronulla riots highlight the fact that social cohesion is the norm, and social conflict the exception, in contemporary Australian society. One key question lingers in the aftermath of Cronulla riots: will Sydney's (and Australia's) minority youth increasingly threaten community cohesion and safety in coming years?

\section{Minority Youth, Identity and Belonging}

Explanations of the criminal and anti-social behavior of minority youth have been sought in their (often unequal) socio-economic characteristics and in youth subjectivities related to issues such as national identity, belonging and inclusion. This section draws on a pilot survey conducted in 2007 of 195 young women and 144 young men aged 14-17 years living in western or south Western Sydney to explore some of the issues identified in the previous sections. The youth were selected to form a stratified sample of youth from a range of the major ethnic groups using a networking methodology. Male and female interviewers were employed to find and interview 10 youth from their different ethnic groups. Most of those youth surveyed were second generation Australians: while three quarters of the sample were Australian-born - the others were born in New Zealand, Sudan, South Korea, Lebanon, Sri Lanka, Vietnam, China, India and Turkey, see Table 1 - only $4 \%$ of the total sample has Australian-born mothers or fathers. Most of the youth were Christians of some kind, with $7.4 \%$ Hindus, $6.5 \%$ Muslim and 4.5\% Buddhist, approximate to the religious 
distribution among Australians as a whole. The majority of youth surveyed (58\%) spoke English at home, with others speaking Tongan (14.5\%), Korean (7.1\%), Tamil (5.3\%), and Chinese (4.4\%) Arabic (2.9\%) While the small sample size precludes definitive, statistically significant results, the survey reveals contradictory social dimensions of the lives of ethnically-diverse young people in Australia today.

Table 1 Country of birth of the young people surveyed

\begin{tabular}{llll}
\hline Country of birth & Males & Females & Total \\
\hline & Per cent/N & Per cent/N & Per cent/N \\
Australia & $74.3 / 107$ & $61.0 / 119$ & $66.7 / 226$ \\
New Zealand & $4.9 / 7$ & $10.3 / 20$ & $8.0 / 27$ \\
Sudan & $3.5 / 5$ & $10.8 / 21$ & $7.7 / 26$ \\
Korea & $4.9 / 7$ & $5.1 / 10$ & $5.0 / 17$ \\
Sri Lanka & $4.2 / 6$ & $3.1 / 6$ & $3.5 / 12$ \\
India & $2.1 / 3$ & $1.5 / 3$ & $1.8 / 6$ \\
South Korea & $2.1 / 3$ & $1.0 / 2$ & $1.5 / 5$ \\
China & $.0 / 0$ & $2.1 / 4$ & $1.2 / 4$ \\
England & $1.4 / 2$ & $.5 / 1$ & $.9 / 3$ \\
Tonga & $.0 / 0$ & $1.5 / 3$ & $.9 / 3$ \\
Other & & $3.0 / 6$ & $2.9 / 10$ \\
\hline Total & $2.8 / 4$ & $100.0 / 195$ & $100.0 / 339$ \\
\hline
\end{tabular}

The issue of national identity among minority youth in Australian multicultural society has long been a contentious issue (Castles, Kalantzis, Cope, \& Morrissey, M., 1988; Sheehan, 1998; Hage, 1998; Castles, 2000). Only one third of the young men and women surveyed identified themselves as “Australian”, despite the fact that two-thirds were born in Australia. One in twenty 'rarely' felt Australian and a fifth of the young people did not really feel Australian at all. On the other hand when asked if the Australian flag was important to them approximately two thirds of the youths thought the flag was important 'often or sometimes'. This supports the argument that minority youth in Sydney have diverse and multiple identities, as Butcher and Thomas (2003), who also

\footnotetext{
${ }^{1}$ Switzerland, Bangladesh, Ethiopia, Africa, Hong Kong, Canada, Egypt, Vietnam, South Africa, and Lebanon
} 
interviewed young people in western Sydney and found that they forged hybrid identities that incorporate their migrant identities with elements of 'being Australian'. Hall's notion that ethnicity is an invention by the self and in relation to, and by, others (Hall, 1987; 1992; 1996) is also useful in understanding this contradiction. That is, we would expect that identity is fluid but also that choices are not available to all equally.

When the young people were asked what the Australian flag meant to them, the most common response was that it was an Australian symbol (70), represented the Australian people, patriotisms (66), being Australian (35), respect (33) and freedom (31). However, there was a group of young people, who thought the flag did not represent anything (66). Taken with responses to questions about national identity this suggests fluidity in subjective belonging: there are moments when minority youth do not feel Australian or identify with the flag but at other times they do, particularly if they belong to transnational communities (Baldasser, 1997).

We also explored the degree to which these minority youth trust other people and found that most have low expectations in trusting people: only one fifth of the youths felt that people could 'always' be trusted, about half of them felt that people could 'sometimes' be trusted and one in ten thought people could 'never' be trusted, with no significant difference in this regard evident for young men and young women. The levels of trust the young people are expressing are lower than the levels of trust expressed by rural young people, who were asked the same question in 2003 (Fabiansson, 2006).

It might be concluded that these findings are supportive of notions that minority youth live parallel lives to other majority youth; that they do not identify with or engage with mainstream, White, Australian society, and that therein lays an explanation for their (occasional) criminality or antisocial behaviour. Such a simplistic conclusion is undermined by other findings from the Sydney survey. The first is the finding that most of the young people surveyed felt good about living in Australia, like living in their Sydney suburb and felt that they belong in local neighbourhoods. Two in three young people reported to "often feeling good about living in Australia" and another one in four young people reported to "sometimes feeling good about living in Australia. On the 
other hand, one in three males and one in four females 'rarely' or 'never' felt ownership of their local area, as Table 2 shows.

\section{Table 2 Ownership of the local place in relation to gender}

\begin{tabular}{llll}
\hline Ownership of the local place & Males & Females & Total \\
\hline & Per cent & & Per cent/N \\
Yes, often & 37.8 & 34.7 & $36.0 / 121$ \\
Sometimes & 30.8 & 40.4 & $36.3 / 122$ \\
Rarely & 10.5 & 11.9 & $11.3 / 38$ \\
No, never & 21.0 & 13.0 & $16.4 / 55$ \\
\hline Total \%/ N & $100.0 / 143$ & $100.0 / 193$ & $100.0 / 336$ \\
\hline Pearson Chi-Square; level of significance; $>.001^{* * *--}$ strong; .001-.009**-- moderate; .01-.05*-- weak. \\
\hline
\end{tabular}

Nor are these minority youth isolated from other youth. Most youth we surveyed have multicultural social networks, evidence that the underlying social cohesion of inter-ethnic youth relations is quite strong in Sydney, not withstanding the rather exceptional events at Cronulla Beach in December 2005. The Sudanese youth surveyed, for example, had as friends 'Australian', Lebanese and Indian youth as well as Sudanese. What these youth most liked about their local area were their social networks and social environment that they found there. When asked to identify “Australian values”, the minority youth listed (in order of frequency) friendship (98), honesty (80), trust (63), family (61), respect (60), loyalty (45), your own personality (41), religion (39), love (32), school, education, knowledge and intelligence (32). Disconnection with schooling is as a key aspect of the social exclusion of immigrant minorities (Reid, 2009). Most of the youth surveyed seemed to connect with their school. About half of the females (52.1\%) and two in five males (42.4\%) reported that the felt valued 'often', with only one in ten males (9.7\%) one in fifty young women feeling that they were not valued at school.

Moreover, only a few of the minority youth surveyed did not feel safe during the day. After dark, the percentage of youths who did feel very safe had more than halved to $24.3 \%$ of the males and $17.4 \%$ of the females. The youths were asked about youth gangs. More than half of the minority 
(198) were not aware of any gangs in their local area. Thirty youths said that there were gangs but they were not aware of their names. Groups based on ethnicity were mentioned by 41 of the youths. The youths were also asked about the Cronulla riots. Most reported that they and their families were not effected by, though those that were responded that they were less likely to go to Cronulla and other non-local places in Sydney as a result. When asked about the likelihood that an event like the Cronulla riots would happen again in Sydney, nearly half of female respondents (46.3 per cent) and one third of male respondents (37.3\%) responded in the affirmative.

\section{Conclusion}

The article has explored the issue of ethnic youth crime and inter-ethnic conflict in Sydney, particularly those related to young people of 'Middle Eastern appearance', probing events, discourses, and evidence and policy responses, situated within a broader international literature on ethnic youth crime. We conclude that the evidence on immigrant criminality is weak, that the panic about immigrant youth crime, the isolation of young people into ethnic enclaves and immigrant youth gangs is disproportionate to the reality and that the media discourses and political opportunism helps to build negative, stereotypical images of young people from minority backgrounds, shifts the criminal gaze from individuals to whole communities in the form of a preoccupation with dysfunctional, disengaged minority cultures and, at the same time, directs attention away from policy responses rooted in the socio-economic disadvantage of many minority youth in Sydney. A review of the events leading up to the Sydney Cronulla Beach riots of December 2005 suggests that the underling cause of the riots were many years of international, national and local anti-Arab, anti-Muslim media discourse and political opportunism, embedded in changing but persistent racist attitudes and practices. Our argument is that such inter-ethnic conflict between immigrant and majority youth in Sydney is the exception, not the rule, and that despite the persistence of racism and prejudice in Australian society social cohesion is the norm, interspersed by moments of social conflict. Probing the construction of minority youth as disengaged from mainstream society we drew on hitherto unpublished primary research data collected in Sydney to explore issues of national identity and belonging among young people of diverse ethnic and religious background living in Sydney today. Here we argue that minority youth in Sydney do not live 'parallel lives' but contradictory cosmopolitan lives. They are connected to family, friends and local place but often disconnected to the nation and the flag. 


\section{References}

Anti-Discrimination Board of New South Wales (2003). Race for the Headlines: racism and media discourse, Anti-Discrimination Board of New South Wales, Sydney.

Baldassar, L. (1997). 'Home and Away: Migration, the Return Visit and "Transnational" Identity’, Communal Plural Home, Displacement, Belonging, v. 5, pp. 69-94

Bam-Hutchison, June (2009). "Race, Faith and UK Policy: a brief history" http://www.york.ac.uk/ipup/projects/raceandfaith/discussion/bam-hutchison.html, accessed 14 July 2009.

Blainey, G. (1984). All For Australia. Sydney: Methuen.

Bowling, B. and Phillips, C. (2002). Racism, Crime and Justice. Harrow Longman Press;.

Butcher, M. \& Thomas, M. (eds) (2003). Ingenious: Emerging Youth Cultures in Urban Australia, Sydney: Pluto.

Castillo, A. and Hirst, M. (2000). “Looking Both Ways: Fairfield, Cabramatta and the Media”, in Jock Collins and Scott Poynting (eds) The Other Sydney: Communities, Identities and Inequalities in Western Sydney, Common Ground, Melbourne, pp.123-140.

Castles, S. (2000). Ethnicity and Globalisation. London, Sage Publications.

Castles, S., Kalantzis, M., Cope, B. and Morrissey, M. (1988). Mistaken Identity - Multiculturalism and the Demise of Nationalism in Australia. Sydney: Pluto Press.

Castles, S. and Miller, M. (2009). The Age of Migration, London, Macmillan, $4^{\text {th }}$ Edn.

Cathcart, Brian (2000). The Case of Stephen Lawrence, Penguin Books, London.

Chan, J. (1994). 'Policing Youth in "Ethnic" Communities', in R. White and C. Alder (eds) The Police and Young People in Australia, Cambridge University Press, Cambridge: 175-198. 
Chan, J. (1997). Changing Police Culture: Policing in a multicultural society, Cambridge University Press, Cambridge.

Chan. W. and Mirchandani, K. eds. (2002). Crimes of Colour: Racialization and the Criminal Justice System in Canada. Peterborough: Broadview Press.

Collins Jock (2003). "Immigrant Crime in Europe and Australia: Rational or Racialised Responses?”, Paper to The Conference on the Challenges of Immigration and Integration in the European Union and Australia, University of Sydney, 18-20 February.

Collins Jock (2005). "From Beirut to Bankstown: The Lebanese Diaspora in Multicultural Australia” in Paul Tabar (ed.) Lebanese Diaspora: History, Racism and Belonging, Lebanese American University, Beirut, Lebanon, pp.187-211.

Collins Jock (2007a). "Immigrants as Victims of Crime in Australia", special issue of the International Review of Victimology, 2007, Vol. 14, pp. 57-79.

Collins Jock (2007b). “The Landmark of Cronulla ' in James Jupp and John Nieuwenhuysen (eds) (2007) Social Cohesion in Australia. Cambridge University Press, Cambridge and Melbourne, pp.61-69.

Collins, Jock, Noble, Greg, Poynting, Scott and Tabar, Paul (2000). Kebabs, Kids, Cops and Crime: Youth Ethnicity and Crime, Pluto Press, Sydney.

Collins, Jock, Noble, Greg, Poynting, Scott and Tabar, Paul (2002). Gangs, Crime and Community Safety: Perceptions and Experiences in Multicultural Australia, UTS Centre for Transforming Culture and UTS School of Finance and Economics, Broadway.

Cook, D. and Hudson, B. (1993). Racism and Criminology. London: Sage. 
Dagistanli, Selda (2007). ‘Like a pack of wild animals’: Moral panics around “ethnic” gang rape n Sydney’. In Scott Poynting and George Morgan (eds.) Outrageous! Moral panics in Australia. Hobart: ACYS Publishing, pp. 181-196.

Dreher, Tanya (2000) 'Cabramatta News Talk: Identity and Symbolic Power.' In Jock Collins and Scott Poynting (eds.) (2000). The Other Sydney: Communities, Identities and Inequalities in Western Sydney. Melbourne: Common Ground, pp. 106-122.

Dunn, Kevin M. \& Forrest, J. (2008). "Contemporary manifestations on racism in Australia", in Gopalkrishnan N. and Hurriyet B. (Ed.) Racisms in the New World Order: Realities of Culture, Colour and Identity. Newcastle, Cambridge Scholars Publishing), pp. 95-106

Ethnic Communities Council of NSW (1999). Ethnic Crime Under the Spotlight, ECCNSW, Sydney. European Monitoring Centre on Racism and Xenophobia (1999) “The Stephen Lawrence legacy”, Equal Voices, Issue No.1 EV7, 8/9/99, pp. 9-11.

Fabiansson, C. (2006). "Being Young in Rural Settings: Young people’s everyday community affiliations and trepidations”, Rural Society, v. 16, n. 1, pp. 47-60.

Forrest, J. \& Dunn, K.M., (2007). “Constructing racism in Sydney, Australia’s largest ethni city”, Urban Studies, 44(4), 699-721.

Francis, R.D. (1981). Migrant Crime in Australia, University of Queensland Press, St. Lucia.

Gilroy, P. 1987 There Ain't No Black in the Union Jack, London: Hutchinson.

Goodall, H., Jakubowicz, A., Martin, J., Randall, L. and Seneviratre, K. (1994). Racism, Ethnicity and the Media, Sydney: Allen \& Unwin.

Hage, Ghassan (1998). White Nation: Fantasies of White supremacy in a multicultural society. Sydney: Pluto Press. 
Hall, S. (1987). Minimal Selves. In Identity: The Real Me (pp.44-6). London: The Institute of Contemporary Arts.

Hall, S. (1992). New ethnicities. In Race, Culture and Difference (pp.252-9). London: Open University.

Hall, S. (1996). Who needs identity? In S. Hall \& P. Dugay (Eds.) Questions of Cultural Identity. London: Sage. 1-17

Hall, S., Critcher, C., Jefferson, T., Clarke, J. and Roberts, B. (1978). Policing the Crisis: Mugging, the State and Law and Order, London: Macmillan.

Hawkins, D.H. ed. (1995). Ethnicity, Race, and Crime: Perspectives across Time and Place. Albany, N.Y.: State University Press of New York.

Hazlehurst, K.M. (1987). Migration, Ethnicity and Crime in Australian Society. Australian Institute of Criminology, Canberra.

Henry, Frances and Bjornson, Marnie (1999). The Racialisation of Crime in Toronto's Print Media: A Research Project. Toronto: School of Journalism, Ryerson Polytechnic University

Henry, Frances, P. Hastings, and B. Freer (1996). "Perceptions of Race and crime in Ontario: Empirical Evidence from Toronto and the Durham Region” Canadian Journal of Criminology 38.

Henry, Frances, Carol Tator, Winston Mattis and Tim Rees (2000). The Colour of Democracy: Racism in Canadian Society. Toronto: Harcourt Brace and Co.

Holdaway, Simon (1996). The Racialisation of British Policing, London: Macmillan.

Huntington, Samuel P. (1997). The Clash of Civilisations and the Remaking of the World Order. New York: Simon \& Schuster.

Huntington, Samuel P. (2004) Who Are We? The Challenges to America's National Identity. New York: Simon \& Schuster. 
James, Carl E. (2002). “’Armed and Dangerous!’ Racializing Suspects, Suspecting Race” in Bernard Schissel and Carolyn Brooks eds. Marginality \& Condemnation: An Introduction to Critical Criminology, Fenwood Publishing, Halifax, Canada, pp. 289-307.

Keith, M. and Murji, K. (1993). "Reifying Crime: Legitimising Racism: Left Realism and the Local Politics of Policing” in W. Ball and J. Solomos eds. Race and Local Politics, London: Macmillan.

Kennedy, L., Murphy, D., Brown, M. and Colquhoun, T. (2005). 'Race riots explode', Sydney Morning Herald, 12 December, pp.1-4/

Kershaw, C., Budd, T., Kinshott, G., Mattinson, J., Mayhew, P. and Myhill A. (2000). The 2000 British Crime Survey, Home Office Statistical Bulletin 18/00. London: Home Office.

Lupton, D. (1999). “Dangerous Places and the 'Unpredictable Stranger’: Constructions of Fear of Crime”, Australian and New Zealand Journal of Criminology, Vol. 32, No. 1, pp.1-15.

Manning, P. (2004). Dog whistle politics and journalism: reporting Arabic and Muslim people in Sydney newspapers. Sydney: Australian Centre for Independent Journalism.

Manning, P. (2006). Us and Them: A Journalist's Investigation of Media, Muslims and the Middle East, Sydney, Random House Australia.

Markus, Andrew (2001). Race: John Howard and the remaking of Australia. Allen and Unwin, Crows Nest.

Marr, David and Wilkinson, Marian (2003). Dark Victory, Allen and Unwin, Sydney.

McIlveen, L. and Downie, S. (2005). 'Second beach brawl - police call for calm as locals plot revenge’. Daily Telegraph, 8 December, p.2.

Mukherjee, S. (1999). "Ethnicity and Crime", paper presented to the $3^{\text {rd }}$ National Outloiok Symposium of Crime in Australia, Australian Institute of Criminology, Canberra. 22-23 March 
Overington, C. and Warne-Smith, D. (2005). 'Countdown to conflict'. Weekend Australian, 17-18 December, pp. 17, 20.

Poynting, Scott (2000). 'Ethnicising Criminality \& Criminalising Ethnicity.' In Jock Collins and Scott Poynting (eds.) The Other Sydney: Communities, Identities and Inequalities in Western Sydney. Melbourne: Common Ground, pp.63-105.

Poynting, Scott (2006). 'What Caused the Cronulla riot?’. Race \& Class 48(1), pp. 85-92

Poynting, Scott (2007). '”Thugs” and 'grubs' at Cronulla'. In Scott Poynting and George Morgan (eds.) Outrageous! Moral panics in Australia. Hobart: ACYS Publishing, pp. 158-170.

Poynting, S., Noble, G., Tabar, P. and Collins, J. (2004). Bin Laden in the suburbs: Criminalizing the Arab Other. Federation Press, Sydney.

Poynting, S. and Noble, G. (2004). Living with Racism: the experience and reporting by Arab and Muslim Australians of discrimination, abuse and violence since 11 September 2001, report to the Human Rights and Equal Opportunity Commission, April, viewed 9 February 2007, http://www.humanrights.gov.au/racial_discrimination/isma/research/index.html.

Phillips, C. and Brown, D. (1998). "Entry into the Criminal Justice System: A Survey of Police Arrests and Their Outcomes”, Home Office Research Study 185. London: Home Office.

Reid, C. (2009) "Schooling responses to youth crime: building emotional capital” International Journal of Inclusive Education, 13, 6.

Sacco, Vincent (2000). "Media Constructions of crime” in Robert Silverman, James Teevan and Vincent Sacco eds. Crime in Canadian Society (sixth edition). Toronto: Harcourt Brace.

Satzewich, Vic ed. (1998). Racism and Social Inequality in Canada: Concepts, Controversies and Strategies of Resistance. Toronto: Thompson Educational Publishers. 
Schissel, Bernard and Brooks, Carolyn eds. (2002). Marginality \& Condemnation: An Introduction to Critical Criminology. Fenwood Publishing, Halifax, Canada

Sheehan, Paul (1998). Among the Barbarians: The Dividing of Australia. Sydney: Random House.

Sheehan, Paul (2006). Girls Like You. Sydney: Macmillan.

Skellington, R. (1996). 'Race' in Britain Today. London: Sage

Solomos, John (1993). Race and Racism in Contemporary Britain. London: Macmillan

The Cantel Report (2002). Community Cohesion. Report of the Independent Review Team. Chaired by Ted Cantel. London: Home Office.

Tonry, Michael ed. (1997). Ethnicity, Crime and Immigration: Comparative and Cross national Perspective. Chicago: University of Chicago Press.

Webster, C. (1997). “The Construction of British ‘Asian’ Criminality”, International Journal of Sociology of Law, 25, 65-86.

Webster, C. (2001). “Representing Race and Crime”, Criminal Justice Matters, No. 43, Spring, 1617.

Wortley, Scott (2001). "Under Suspicion: Race and Criminal Justice Surveillance in Canada” in W. Chan. and K. Mirchandani, eds. (2002) Crimes of Colour: Racialization and the Criminal Justice System in Canada. Peterborough: Broadview Press.

Wortley, Scott (2002). "Misrepresentation or Reality? The Depiction of Race and Crime in the Toronto Print Media” in Bernard Schissel and Carolyn Brooks, eds. (2002) Marginality \& Condemnation: An Introduction to Critical Criminology, Fenwood Publishing, Halifax, Canada, pp. 55-82 